\title{
DYNAMIC RESPONSE OF A BASE-ISOLATED CONCRETE RECTANGULAR LIQUID-STORAGE STRUCTURE UNDER LARGE AMPLITUDE SLOSHING
}

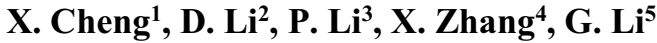

\begin{abstract}
Considering concrete nonlinearity, the wave height limit between small and large amplitude sloshing is defined based on the Bernoulli equation. Based on Navier-Stokes equations, the mathematical model of large amplitude sloshing is established for a Concrete Rectangle Liquid-Storage Structure (CRLSS). The results show that the seismic response of a CRLSS increases with the increase of seismic intensity. Under different seismic fortification intensities, the change in trend of wave height, wallboard displacement, and stress are the same, but the amplitudes are not. The areas of stress concentration appear mainly at the connections between the wallboards, and the connections between the wallboard and the bottom.
\end{abstract}

Keywords: large amplitude sloshing; earthquake; base-isolated; concrete; rectangular liquid-storage structure; nonlinearity; dynamic response

\section{INTRODUCTION}

When the petrochemical supply, water supply, or drainage storage tanks are under seismic action while the civilian aircraft, space shuttle, or spaceship is in flight (or the ship is at sea), the sloshing amplitude of the liquid in the liquid-storage structure is large, especially when the natural

\footnotetext{
${ }^{1}$ Prof., PhD., Eng., Lanzhou University of Technology, Faculty of Civil Engineering, Lanzhou, 730050, PR China, e-mail: chengxuansheng@gmail.com (Xuansheng Cheng)

2 B.S., Eng., Lanzhou University of Technology, Student of Civil Engineering, Lanzhou, 730050, PR China, e-mail: 916556958@qq.com (De Li)

${ }^{3}$ M.S., Eng., Lanzhou University of Technology, Faculty of Civil Engineering, Lanzhou, 730050, PR China, e-mail: 345359998@qq.com (Peijiang Li)

${ }^{4}$ B.S., Eng., Lanzhou University of Technology, Student of Civil Engineering, Lanzhou, 730050, PR China, e-mail: 1525507465@qq.com (Xiaoyan Zhang)

${ }^{5}$ B.S., Eng., Lanzhou University of Technology, Student of Civil Engineering, Lanzhou, 730050, PR China, e-mail: 1340523276@qq.com (Guoliang Li)
} 
frequency of the sloshing liquid is close to the vibration frequency of the concrete rectangular liquid-storage structure (CRLSS). The harm is far greater than the small amplitude sloshing. The sloshing problem of this type of liquid (with a free surface) involves solving the initial boundary value problem (Yue et al., 1999; Haroun and Chen, 2015) for Navier-Stokes equations in mathematics. The position of the free surface is a complex nonlinear equation, which is quite difficult to solve and has only been solved through a numerical simulation method up to this point. There are many methods to numerically simulate large amplitude sloshing with free liquid surfaces. Common methods include the MAC method (Amsden and Harlow, 1970), the VOF method (Hirt and Nichols, 1981), FEM, and BEM.

Based on the momentum conservation of liquids, Goudarzi et al. (2010) studied the impact force of large amplitude sloshing caused by earthquakes on the top plate of the liquid-storage structure. Nie and Shi (2010) studied the effect of truncation errors on the large amplitude sloshing of the CRLSS, using the CFD method to solve discrete equations. Bouabidi A.(2013) et al. established a two-dimensional numerical wave tank based on the Navier-Stokes equations. Gui and Jiang (2014) studied the problem of large sloshing of liquid-storage structures under resonance excitation by using a numerical simulation method. Cheng et al. (2015a; 2015b) assumed that the liquid is incompressible, and studied the liquid-solid interaction seismic response of an isolated overground CRLSS. Cheng et al. (2015c) showed that rubber isolation bearings can filter out the high-frequency components of external excitation, so that, theoretically, high-frequency resonance does not occur. However, when the external excitation frequency is close to the first-order frequency of the liquid, a significant resonance dynamic response appears. Therefore, the isolation period should be chosen in accordance with the first order frequency.

In summary, there is currently no relevant data about research on the dynamic response of a base-isolated CRLSS under large amplitude sloshing, and the influence of concrete materials has not been considered. Therefore, in this paper, wave height limits of large amplitude sloshing and small amplitude sloshing are obtained based on the Bernoulli equation. Based on Navier-Stokes equations, a mathematical model of large amplitude sloshing is established, and the seismic response of a CRLSS under large amplitude sloshing is studied. 


\section{Determination of large amplitude sloshing}

With regard to large amplitude sloshing and small amplitude sloshing, small amplitude sloshing is seen as no more than $1 \%$ of the depth of the liquid. When considering the Bernoulli equation $p+\frac{\rho|U|^{2}}{2}+\rho g \eta=c$ and satisfying the condition that $\frac{1}{2}|U|^{2}$ is far less than $g \eta$; namely, the liquid sloshing is linear, and the nonlinear square term (Liu and Huang, 1993) is neglected. Assuming that the response frequency is $\omega_{r}$, the movement rate $|\mathrm{U}|$ is approximately equal to $|\omega \eta|$ in magnitude. There is

$$
|\eta| \leq \frac{2 \varepsilon g}{\omega_{2}^{2}}
$$

where:

$\frac{2 \varepsilon g}{\left(\omega_{2}\right)^{2}}$ is defined as the critical amplitude $\eta_{0}$ when the sloshing amplitude is less than the critical sloshing amplitude, namely $|\eta|<\left|\eta_{0}\right|$. The small amplitude hypothesis is applicable. When the sloshing amplitude is more than the critical amplitude, namely, $|\eta| \geq\left|\eta_{0}\right|$, the nonlinear term of the Bernoulli equation $\frac{1}{2}|U|^{2}$ must be considered. For a liquid, the critical amplitude is decided by the sloshing frequency, while in cases of small amplitude sloshing and linear sloshing, the effect of external excitation on the response frequency of the stored liquid is not significant. Thus, the response frequency can be replaced by the natural frequency of the corresponding mode, namely,

$$
\eta_{0}=\frac{2 \varepsilon g}{\omega_{0}^{2}}
$$

For a two-dimensional rectangular container, the natural frequency can be obtained directly through the dispersion equation of ideal potential fluid, namely, 


$$
\omega_{0}^{2}=\frac{n \pi g}{2 b} \tanh \left(\frac{n \pi d}{2 b}\right)
$$

where:

$n$ - the nth order mode, $d$ - the depth of the stored liquid, and $b$ - the width of the wallboard of the CRLSS.

When the wave height of the liquid sloshing is larger than the critical value, the hypothesis of small amplitude can be discarded, and the focus of the research can be the seismic response of the CRLSS under large amplitude sloshing.

\section{Calculation parameters and calculation model}

\subsection{CAlCulation PARAMETers}

In this paper, the constitutive model of concrete proposed by Sargin et al. is adopted (Zhao, 2014). The mechanical property of the rubber isolation cushion is described through the constitutive relationship of the Mooney-Rivlin model.

The density of reinforced concrete is assumed to be $2500 \mathrm{~kg} / \mathrm{m}^{3}$, the concrete strength grade is $30 \mathrm{MPa}$, Poisson's ratio is $v=0.2$, the elastic modulus is $\mathrm{E}_{\mathrm{c}}=3.0 \times 10^{4} \mathrm{~N} / \mathrm{mm}^{2}$, and the shear modulus is $\mathrm{G}_{\mathrm{c}}=1.2 \times 10^{4} \mathrm{~N} / \mathrm{mm}^{2}$. The steel bar of the wallboard and the bottom plate of the CRLSS are bidirectional, $14 \mathrm{~mm}$ in diameter and $150 \mathrm{~mm}$ in spacing. The steel's Poisson's ratio is $v=0.3$, the elastic modulus is Es $=2.0 \times 10^{5} \mathrm{~N} / \mathrm{mm}^{2}$, and the shear modulus is $\mathrm{Gs}=0.8 \times 10^{5} \mathrm{~N} / \mathrm{mm}^{2}$.

The liquid is considered the potential fluid material. The bulk modulus of the liquid is chosen as $2.3 \times 10^{3} \mathrm{~N} / \mathrm{mm}^{2}$, and the density is chosen as $1000 \mathrm{~kg} / \mathrm{m}^{3}$.

A rubber cushion with a thickness of $0.2 \mathrm{~m}$ is adopted, and $\mathrm{C}_{1}=0.206$ and $\mathrm{C}_{2}=0.0103$ are chosen.

\subsection{Calculation model}

To study the liquid sloshing in a CRLSS more clearly, a reinforced CRLSS without a cover is used in this paper. The lengths of the three edges are chosen as $a \times b \times h=6 \mathrm{~m} \times 6 \mathrm{~m} \times 6 \mathrm{~m}$ and the 
thickness of the wallboard and the bottom plate of the CRLSS are both chosen as $0.3 \mathrm{~m}$. When synthetically considering the liquid sloshing, liquid height is $\mathrm{H}=4.5 \mathrm{~m}$ and the thickness of the isolation layer of the rubber cushion is $0.2 \mathrm{~m}$. A 3D-solid element is chosen for the structural element, and a 3D potential fluid element is chosen for the fluid. The fluid's surface is defined as a free surface, and a three-dimensional calculation model is established.

According to Eq. (2.2), the length, width, and height of the CRLSS are all $6 \mathrm{~m}$ and the height of the liquid is $\mathrm{H}=4.5 \mathrm{~m}$. The wave height limit of both the linear small amplitude sloshing and the nonlinear large amplitude sloshing is $0.606 \mathrm{~m}$.

\subsection{SEISMIC WAVE}

To study the dynamic characteristics of a base-isolated CRLSS, the El Centro wave is chosen. When calculating, the seismic wave record of $30 \mathrm{~s}$ is chosen and the bidirectional seismic waves (waves NS and EW) are inserted into the three-dimensional calculation model. Then, the variation of the liquid sloshing amplitude, the displacement of the wallboard, the stress and strain and acceleration time history of the base-isolated CRLSS (under the seismic wave of seismic fortification intensity 7,8, and 9 on the basis of the newly published Chinese Code for seismic design of building GB50011-2010) are respectively considered.

\section{Dynamic responses}

\subsection{SLOSHING WAVE HEIGHT}

The earthquake waves of seismic fortification intensity 7,8, and 9 are input in the $x$ and $y$ directions and the parameters of the isolation cushion are adjusted so that the liquid produces large amplitude sloshing. The calculation results of the wave height of the sloshing liquid are shown in Table 1. 
Table 1 Maximum liquid sloshing height /[m]

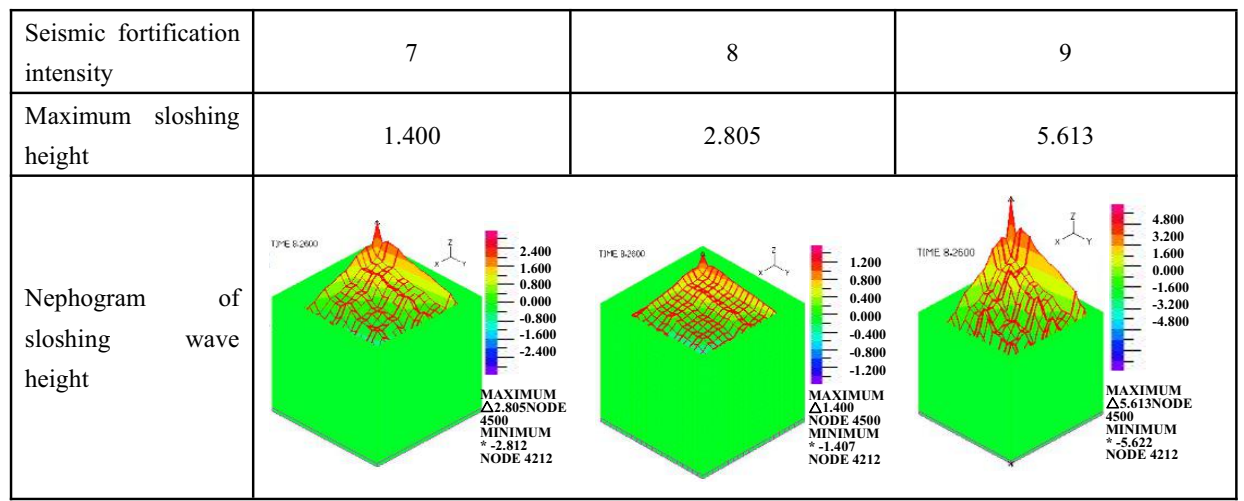

As seen from Table 1, when considering the nonlinear stress-strain relationship of concrete, the maximal displacement of liquid sloshing increases with the increase of seismic intensity. Growth rates are all $100 \%$ when seismic fortification intensity changes from 7 to 8 and from 8 to 9 .

\subsection{WALLBOARD DISPLACEMENT}

The parameters of the isolation cushion are adjusted to make the liquid produce large amplitude sloshing. The calculation results of wallboard displacement are shown in Table 2, when seismic fortification intensities are 7,8 , and 9 .

Table 2 Maximum displacement of wallboard /[m]

\begin{tabular}{|c|c|c|c|}
\hline $\begin{array}{l}\text { Seismic fortification } \\
\text { intensity }\end{array}$ & 7 & 8 & 9 \\
\hline Displacement & 0.044 & 0.088 & 0.178 \\
\hline $\begin{array}{l}\text { Wallboard } \\
\text { displacement } \\
\text { nephogram }\end{array}$ & & & \\
\hline
\end{tabular}


From Table 2, it is observed that when considering the nonlinear characteristics of concrete, maximum displacement values of the wallboard appear at the two wallboards in the plane normal to the direction of the earthquake wave. This shows that the peak value of earthquake acceleration time history is greater in the $x$ direction of the earthquake wave than in the $y$ direction of earthquake wave.

\subsection{WALLBOARD STRESS}

The smooth equivalent stress, the maximum shear stress, the first principal stress, and the third principal stress of a CRLSS under seismic fortification intensity 7 are shown in Fig. 1. The smooth equivalent stress, the maximum shear stress, the first principal stress, and the third principal stress of a CRLSS under seismic fortification intensity 8 and 9 are omitted. The maximum stress values of the wallboard under different seismic intensities are shown in Table 3 .



(a)Equivalent stress

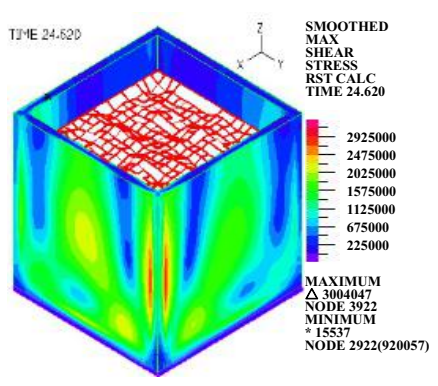

(b) Maximum shear stress 




(c) The first principal stress

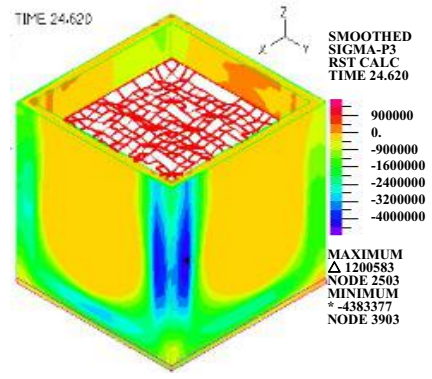

(d) The third principal stress

Fig. 1 Stress nephogram of a wallboard under seismic fortification intensity 7

Table 3 Stress value of the wallboard under different seismic intensity /[MPa $]$

\begin{tabular}{|l|c|c|c|}
\hline Seismic fortification intensity & 7 & 8 & 9 \\
\hline Equivalent stress & 5.504 & 8.492 & 14.420 \\
\hline Maximum shear stress & 3.004 & 4.634 & 7.881 \\
\hline The first principal stress & 5.447 & 8.433 & 14.520 \\
\hline The third principal stress & 1.201 & 1.853 & 3.169 \\
\hline
\end{tabular}

As seen in Fig. 1 and Table 3, with the increase of seismic intensity, the equivalent stress of the wallboard, the maximum shear stress, the first principal stress, and the third principal stress increase in turn. The equivalent stress increase is $35 \%$ when the seismic intensity changes from 7 to 8 degrees, and the increase is $41 \%$ when the seismic intensity changes from 8 to 9 degrees. The maximum equivalent stress mainly appears at the junction of the wallboards, and reaches a 
maximum value at the top of the wallboard. It first decreases and then increases from the connection point of the wallboard to the center line of the wallboard. It's observed that the maximum equivalent stress of the wallboard appears in the place at which the wave height of the sloshing liquid is at its maximum, thus, the liquid sloshing pressure present in that area is larger. The stress concentration mainly appears at the junction of the wallboards, the junction of the wallboard and the bottom plate, and the middle part of the wallboard.

\section{Conclusions}

(1) Considering the nonlinearity of concrete, the response of the CRLSS increases gradually with the increase of seismic intensity; when the CRLSS is under the effect of different seismic intensities.

(2) During earthquakes of varying intensity, the trends of the change of wave heights of the liquid sloshing, wallboard displacement, and stress of the CRLSS are the same. Only the amplitude values differ.

(3) Stress appears mainly at the middle part of the wallboard and the edge of the wallboards near the junction. This is the weakest part of the CRLSS, and strengthening it is considered possible through adopting fortifying measures in its structural design.

\section{Acknowledgments}

This paper is a part of the National Natural Science Foundation of China (Grant number: 51368039), and a part of the Plan Project of Science and Technology in Gansu province (Grant number: 144GKCA032). 


\section{References}

1. Amsden A.A. and Harlow F.H. A simplified MAC technique for incompressible fluid flow calculations, Journal of Computational Physics,1970, 6(2):322-325.

2. Bouabidi A., Driss Z. and Abid M.S. Vertical baffles height effect on liquid sloshing in an accelerating rectangular tank, International Journal of Mechanics and Applications, 2013,3(5):105-116.

3. Cheng X.S., Cao L.L., and Zhu H.Y., Liquid-solid interaction seismic response of an isolated overground rectangular reinforced-concrete liquid-storage structure, Journal of Asian Architecture and Building Engineering, 2015(a),14(1):175-180. 2015(a).

4. Cheng X.S., Chen W.J., Zhu H.Y. Effects of base isolation on seismic response of concrete rectangular tank, Electronic Journal of Geotechnical Engineering, 2015(b),20(8):2149-2166.

5. Cheng X.S., Zhao L., Zhang A.J., et al. FSI resonance response of liquid-storage structures made of rubber-isolated rectangular reinforced concrete, Electronic Journal of Geotechnical Engineering, 2015(c),20(7):1809-1824.

6. Gui F.K. and Jiang S.C. Numerical Simulation of Liquid Sloshing Problem under Resonant Excitation, Advances in Mechanical Engineering, 2014,6(1):701-709.

7. Goudarzi M.A., Sabbagh-Yazdi S.R., Marx W. Seismic analysis of hydrodynamic sloshing force on storage tank roofs, Earthquake Spectra, 2010,26(1):131-152.

8. Haroun M.A. and Chen W. Seismic large amplitude liquid sloshing-theory, Seismic Engineering @ Research and Practice, ASCE, 2015.

9. Hirt C.W. and Nichols B.D. Volume of fluid (VOF) method for the dynamics of free boundaries, Journal of Computational Physics, 1981,39(1):201-255.

10. Liu Z.H. and Huang Y.Y. An arbitrary Lagrangian-Eulerian boundary element method for large-amplitude sloshing problems, Journal of Vibration Engineering, 1993,6(1):10-18.

11. Nie L.Y. and Shi X.L. Discussion on method of estimating the effect range of truncation error in large amplitude sloshing of water in rectangular duct, Chinese Journal of Computational Mechanics, 2010,27(4):624-628.

12. Yue B.Z., Liu Y.Z. and Wang Z.L. Review of the numerical methods for simulating large -scale amplitude sloshing of liquid, Journal of Shanghai Jiaotong University, 1999,33(6):760-763.

13. Zhao Y.R. FSI resonance response of rubber isolated rectangular reinforced concrete liquid-storage structures, Lanzhou: Lanzhou University of Technology, 2014. 


\section{LIST OF FIGURES AND TABLES:}

Fig. 1. Stress nephogram of a wallboard under seismic fortification intensity7

Rys. 4 Schemat naprężenia płyty regipsowej pod wpływem oddziaływania sejsmicznego 7

Table 1. Maximum liquid sloshing height /[m]

Tabela 1. Maksymalne rozchlapywanie płynu: wysokość/[m]

Table 2. Maximum displacement of wallboard /[m]

Tabela 2 Maksymalne przemieszczenie płyty regipsowej/[m]

Table 3. Stress value of the wallboard under different seismic intensity /[MPa]

Tabela 3 Wartość naprężenia płyty regipsowej pod wpływem różnych oddziaływań sejsmicznych /[MPa] 


\title{
DYNAMICZNA ODPOWIEDŹ PROSTOKĄTNEJ STRUKTURY MAGAZYNOWANIA SUBSTANCJI CIEKŁYCH Z WYKORZYSTANIEM BETONU IZOLACYJNEGO
}

\author{
Słowa kluczowe: chlupotanie o dużej amplitudzie; trzęsienie ziemi; izolacyjny; beton; prostokątna struktura \\ magazynowania substancji ciekłych; nieliniowość; dynamiczna odpowiedź
}

\section{STRESZCZENIE:}

Gdy amplituda chlupotania cieczy jest zbliżona do częstotliwości drgań struktury magazynowania substancji ciekłych (CRLSS), wówczas osiągamy rezonans i możemy zaobserwować silne zjawisko nieliniowe. Szkoda jest znacznie większa niż chlupotanie o małej amplitudzie.

Obecnie brak jest odpowiedniego raportu na temat badań dynamicznej odpowiedzi struktury magazynowania substancji ciekłych z wykorzystaniem betonu izolacyjnego (CRLSS) z chlupotaniem o dużej amplitudzie, a wpływ materiałów betonowych nie jest brany pod uwagę. W związku z tym, w niniejszej pracy, w oparciu o równanie Bernoulliego, otrzymano ograniczone wysokości fali o dużej amplitudzie chlupotania oraz małej amplitudzie chlupotania. Na podstawie równań Naviera-Stokesa ustanowiono matematyczny model chlupotania o dużej amplitudzie i zbadano odpowiedź sejsmiczną CRLSS podczas chlupotania o dużej amplitudzie.

Rozważając równanie Bernoulliego i zadowalający stan, chlupotanie substancji ciekłej jest liniowe, a nieliniowy kwadratowy człon jest lekceważony.

W stałym i płynnym interfejsie, struktura magazynowania substancji ciekłych spełnia warunki ciągłości przemieszczania i równowagi siły oddziaływań.

Właściwość mechaniczna gumowego zabezpieczenia izolacyjnego została opisana w oparciu o konstytutywną relacje modelu Mooney-Rivlin.

W celu głębszego zbadania chlupotania substancji ciekłych w CRLSS w niniejszej pracy, zastosowano wzmocnioną CRLSS bez pokrycia. Stały element 3D został wybrany dla elementu konstrukcyjnego, natomiast potencjalny płynny element 3D został wybrany dla płynu. Powierzchnia płynu została określona jako wolna powierzchnia.

Wytwarzanie chlupotania płynu o dużej amplitudzie odbywa się poprzez ustawienie parametrów gumowego zabezpieczenia izolacyjnego.

Wybrano realistyczne parametry w celu zwiększenia wysokości fali chlupotania cieczy powyżej $0,606 \mathrm{~m}$. Na tym etapie dynamiczna odpowiedź CRLSS może być zbadana poprzez analizę wysokości fali chlupotania cieczy, przemieszczenia płyty ściennej okładzinowej oraz naprężenia. 
W celu zbadania dynamicznych cech izolacyjnego CRLSS, mając na uwadze fakt, iż fala sejsmiczna historii czasu przyspieszenia jest łatwa do określenia i zastosowania, biorąc pod uwagę wymagania amplitudy, częstotliwość oraz czas działania fali sejsmicznej, wybrano falę El-Centro. Podczas dokonywania obliczeń wybrano zapisy fali sejsmicznej $\mathrm{z}$ lat 30-tych, a dwukierunkowe fale sejsmiczne (fala NS i fala EW) zostały wprowadzone do trójwymiarowego modelu obliczeniowego. Następnie, wariacja amplitudy chlupotania cieczy, przemieszczenie płyty ściennej okładzinowej, naprężenie i odkształcenie, historia czasu przyspieszenia, itp. RLSS betonu izolacyjnego w fali sejsmicznej o intensywności sejsmicznej fortyfikacji wynoszącej 7, 8 i 9 zostały odpowiednio uwzględnione.

Biorąc pod uwagę nieliniowość betonu, odpowiedź CRLSS stopniowo wzrasta wraz ze wzrostem intensywności sejsmicznej, gdy CRLSS znajduje się pod różnymi intensywnościami sejsmicznymi.

Podczas trzęsień ziemi o różnej intensywności, tendencja zmiany wysokości fali chlupotania cieczy, przemieszczenia płyty ściennej okładzinowej oraz naprężenia CRLSS jest taka sama. Jedynie wartości amplitudy są różne.

Koncentracja naprężeń występuje przede wszystkim u zbiegu płyt ściennych okładzinowych, u zbiegu płyty ściennej okładzinowej i płyty dolnej, jak również pośrodku płyty ściennej okładzinowej. Jest to słaba część CRLSS, którą uważa się za wzmacnianą poprzez zastosowanie środków strukturalnych w projektowaniu konstrukcyjnym. 